\title{
The Role and Value of Graphic Representation of Knowledge Structures in ESL Student Learning: An Ethnographic Study
}

Gloria M. Tang

This article reports an ethnographic study of two multicultural seventh grade classes. It was designed to explore the role and value of graphic representation of knowledge structures in ESL student learning, based on a specific definition and categorization of knowledge structures (Mohan 1986). Findings revealed that students were exposed to, and interacted with, a quantity of graphics in curriculum and instruction. However, whether, and how, students used graphics to facilitate learning depended to a large extent on the guidance they received. Without teacher guidance, students could not successfully extract information from graphics, or use graphics to represent knowledge, or recognize graphics as an alternative way of communicating knowledge. They perceived the function of graphics to be decorative, and their general attitude towards graphics was negative. With explicit teacher guidance, however, students were more likely to take advantage of graphic representation of knowledge structures to facilitate learning.

Teachers of English as a second language (ESL) have for centuries been interested in finding better ways to help students understand and retain knowledge they encounter in the classroom and in text materials which they are required to read. One of the teaching/learning strategies which has received much attention is the use of graphics and illustrations to aid student learning.

Various learning theories have prompted educators to devise graphic tools to facilitate student comprehension, e.g., Ausubel's cognitive theory (Ausubel 1968), schema theory, the Gestalt theory of perception, and Paivio's dual code model (Paivio 1971). It has also been argued that because graphics allow students to use alternative systems of logic, "certain physiological strengths of learners... can be exploited" (Winn 1987, p. 160). ESL teachers maintain that an effective way to "adapt a lesson which has been successful with a class of English-speaking students" (Mohan 1986, p. 25) to ESL students is to use visuals and graphics (Martinez 1984, cited by Mohan 1986).

Considerable research effort has gone into exploring the effectiveness of graphics and illustrations in promoting comprehension and retention of text information, particularly in the last fifteen years (Willows \& Houghton 1987). Moreover, the interest in this area is growing as evidenced by the frequency of reviews of research on graphics and illustrations (Duchastel 1980; Schallert 1980; Levie \& Lentz 1982; Levin, Anglin \& Carney 1987); the 
sensitivity of reviewers to the differences in objectives and variables of different research studies such as learner characteristics, picture variable, text variable and picture-text variable (Peeck 1987; Levin et al. 1987); the number of conceptual frameworks for classifying graphics and illustrations (Duchastel 1978; Fry 1983; Hunter, Crismore \& Pearson 1987); and, more recently, the appearance of studies on the history of illustrations in textbooks (Mulcahy \& Samuels 1987), and analyses of illustrations as they actually appear in textbooks (Evans, Watson \& Willows 1987; Hunter et al. 1987).

In short, theories of learning support the use of graphics to facilitate student learning, basic research on the influence of various types of graphics and illustrations on student learning is voluminous, and results of all recent reviews conclude that graphics facilitate student learning to some degree. Besides, inquiry into the more practical aspects of graphics and illustrations shows that "considerably more attention is given to illustrations and the design of books now than in the past" (Evans et al. 1987), and that the syntactic text parallels between the illustration and the content of the text have improved.

While all these findings are important, "of primary importance for the effect that illustrations may have is ... what the reader does with a picture" (Peeck 1987, p. 130). Unfortunately, there has been little documentation of the use of illustrated educational materials by students and teachers. Whether graphics are found in instruction, and what teachers and students do with illustrations in instructional materials in classroom situations, have received little attention. Moreover, although researchers have directed our attention to the value and unique characteristics of naturalistic inquiry as a technique well-suited to the examination of how pictures are used by teachers and students (Brody 1984), research employing the technique of actually going into a classroom and observing whether and how graphics are made use of is almost non-existent.

The only naturalistic study which investigated the ways in which textbook illustrations were used in the classroom (Evans et al. 1987) offers only minimal comment of how teachers actually used illustrations, because the researchers had to terminate their project after about 20 hours of observation. There is thus a glaring gap in the research literature on the role of graphics in the classroom and how they are actually used by teachers and students. Or as Peeck (1987) maintains, "not much is known either in research or in reallife settings, about what subjects do with illustrated text [and graphics in curriculum and instruction, for that matter], that is, how 
and when (or indeed whether at all) they use pictures" (Peeck 1987, p. 144). This study was an attempt to fill this gap.

\section{The Research Design}

A naturalistic inquiry (Brody 1984) using ethnographic techniques (Wolcott 1987) was conducted, and the natural setting of two seventh grade classrooms in an elementary school in Vancouver was the primary source of data.

Methods included detailed classroom observation, informal interview of students and teachers, examination of textbooks and other instructional materials, and examination of student assignments and test papers.

Selection of participants was based on judgment sampling (Burgess 1984). This particular elementary school was chosen because $80 \%$ of the students in the seventh grade were ESL students representing a wide range of ethnic groups. I was making a description of a particular cultural setting as I saw it and interpreting data in terms of a particular situation within a particular time frame.

The locations that were intensely observed were two seventh grade classrooms, the library, and the foyers outside the classrooms. The participants were the 56 students who were regularly in one or other of the two seventh grade classes, Division A and Division B. Of the 35 boys and 21 girls, ten were English speaking: eight Canadian, one English and one Scottish. The rest could all fit into the category of ESL, which, for the purpose of this study, is defined as overseas students or visa students, "immigrants or Canadian born inhabitants who identify themselves to some relevant degree with a linguistic heritage other than that of English" (Burnaby 1987, p. 10). The sample represented a wide range of nationalities: Chinese from China, Hong Kong, Taiwan, Malaysia or Vietnam who spoke Cantonese or one of the Chinese dialects (19). Others were from Fiji (9), India and Pakistan (9), the Philippines and Singapore (2), Kenya (2), Czechoslovakia (2), Guatemala (2), and Denmark (1). Their length of residence in Canada ranged from four months to 13 years. A large number of them were born here. However, nearly all of them spoke their first language at home. Twenty-eight indicated that their parents spoke very little English or no English at all. They were all LEP students representing a wide range of abilities within the category. Most of them had difficulty with the language demands of the curriculum, and some even had difficulty communicating in English. 


\section{Conduct of the Study}

Data were gathered in the Fall of 1988 and in February of the following year. All subject areas on the timetable were observed except art, music and physical education. Altogether 163 lessons were intensively observed, 80 in Division A and 83 in Division B. The lessons varied in length from 20 to about 50 minutes.

To maintain an attitude of respect towards the world of the classrooms, and to reduce the possibility of distortion due to the presence of a stranger (Brody 1984), I began by being an unobtrusive observer, but gradually became a participant observer as the students showed signs of acceptance of my presence and participation. My role, as perceived by them, was at times a teacher aide who could answer their questions, and help them with their assignments, and at other times a student teacher who could use their advice and information on teaching, the school and the routine of the class. Although at the beginning, I was painfully aware of myself as an outsider and an intruder, I soon found that I could not hope for a better research site in terms of accessibility, unobtrusiveness, permissibleness and participation (Spradley 1980).

I employed various data collection strategies in addition to observation and participant observation. To find out the types and quantity of graphics in the curriculum, I examined textbooks and instructional materials used during the observation period for existence of graphics. I interviewed to find out if they paid attention to graphics and interacted with them. The documents which yielded the richest data by far on graphics which students interacted with were their assignments. I analyzed social studies projects, science projects, reading assignments, a number of shortterm assignments, test papers and journals. The examination of assignments was followed by discussions with students.

Interviews of teachers were informally conducted before lesson started, at recess or lunch break. They provided information on the standard and background of students, on instructional materials used and not used, and on their preferred teaching style. Students were interviewed during lessons usually when they were engaged in silent reading or in the process of completing a project or some homework assignment, and at recess. These were recorded on the spot or immediately after the interview.

\section{Findings of the Study}

\section{Graphics Students Were Exposed To}

Graphics which students were exposed to in textbooks and instructional materials varied from those which are purely 
decorative to those which explain, represent, interpret, or organize information. Textbooks are highly illustrated, and graphics exist in other instructional materials, i.e., handouts and reference books. In more recently published textbooks, graphics are intended to be comprehension aids and not mere ornaments. Another characteristic of the graphics in textbooks is that the authors have been careful to place illustrations so as to create good "spatial relationships between text and illustration" (Goldsmith 1987, p. 66), which should facilitate comprehension. It is true, though, that the reference to the illustration is seldom directive, i.e., the text seldom draws students' attention to the illustration. Teacher's guides accompanying textbooks also emphasize the use of graphics to present information. Thus, students have the chance to encounter a large quantity of graphics which represent all knowledge structures in the Knowledge Framework (Mohan 1986) if the teacher decides to follow the suggestions in the teacher's guide.

\section{Did Students Pay Attention to Graphics in Instructional Materials and Instruction They Were Exposed To?}

When students encountered graphics in textbooks and other instructional materials, some passed over them after a quick look, others did not even look. During silent reading or completion of assignment, when I had the chance to approach individual students to ask about a graphic they had just come across in their textbook or story book, ten out of ten admitted that they had not looked at it. This was true of graphics which are mainly decorative, those which are illustrative of vocabulary, as well as those which represent and simplify text passages.

In a social studies class, students were asked to "name the four major groups of early people who lived during the period from 1.75 million years ago to 50 thousand years ago, from the earliest to the most recent," the answer to which could be found in a paragraph on page two to page three of the textbook. The same information is simplified in a time line coloured gold and orange immediately following the paragraph. The graphic serves a summarizing function (Hunter et al. 1987). The value of visual summaries has been acknowledged by graphic experts, such as Tuft (1986) and Wainer (1984) (Hunter et al. 1987). However, when I went round the class to see what students did with the graphic, I discovered that nobody took advantage of the visual summary to answer the question. Instead they were all busy looking for, reading or copying the sentence from the text. Nobody even looked at the time line. They did not seem to associate the time line with the information in the 
paragraph, although the graphic is on the same page as the text it summarizes. Nor did it occur to them to examine the time line. They had been told that the answer could be found in the text and that was where they looked to obtain the information. It could be because students did not realize that the text and the graphic are giving the same information in a different form, or that graphics are a device "by which the authors clarify their exposition" (Herber 1970, p. 104).

It appears that students did indeed "tend to skip over visual aids entirely or pay only cursory attention to them" (Vacca 1981, p. 208) unless there was real curricular need. Few interacted with the graphics they encountered unless the teacher or the assignment required them to study, write about, or reproduce them. In other words, the types and quantity of graphics students interacted with and the way students interacted with them depended on what the teacher did with illustrations.

\section{The Teachers}

The teachers of Division A seemed to prefer student inquiry. They encouraged students to use multiple resources, and set assignments which involved research and reading of reference books on the part of students. They usually set the topic, distributed question papers, gave explicit instructions on the requirements, arranged for them to use the library, and left students much on their own. Intensive observation of the class, and analysis of the time students spent on various activities revealed that $77 \%$ of class time was engaged in silent reading and completing assignments. Only a small proportion of the graphics students interacted with was presented by the teacher.

The class teacher of Division B appeared to prefer teaching from a set of curriculum materials of his choice and reinforcing its content through structured field trips, controlled classroom activities, and assignments and tests. The assignments were mostly short-term, and set after the teacher had guided the students step by step through the tasks, or, at least, after ample examples.

\section{Graphics Students Interacted With}

For the purpose of this report, interaction with graphics is defined as reading, interpreting, copying, constructing, answering questions on, or explaining them. In both Divisions students had to interact with graphics representing all six knowledge structures. The teachers had set assignments which involved graphics. It was only 
when there was curricular demand that students paid attention to, and interacted with, graphics.

Did Students Have Difficulty Presenting Knowledge in Graphic Form?

In both Divisions, the students did not know how to use graphics to explain (Duchastel 1978), represent (Levin et al. 1987) or reinforce (Hunter et al.), organize and interpret (Levin et al. 1987) knowledge. It appears that even when students had gathered relevant or related data, they had difficulty organizing and presenting them. They had no idea what format to use and what categories and information to select. It is often assumed that students are capable of processing and producing illustrative material when they are simply told to do so. However, this assumption is questionable, for "competency in adequately dealing with illustrations develop[s] only gradually" (Peeck 1987, p. 133). Or, as Herber (1970) states, graphics seem to be absolutely unnecessary to 'teach.' However, he maintains, "many understandings appear obvious after they have been understood ... They are not obvious to the person struggling to acquire the insight" (Herber 1970, p. 103). Students appeared to need more than mentioning, i.e., "saying just enough about an assignment so that students understood the formal requirements of the task, but stopping short of demonstrating how to solve the task cognitively" (Pearson 1985, p. 730), to perform the task.

In a group project in which they had to present information in a large chart, the students made no attempt to edit, organize or integrate data. The failure of students to produce complete and accurate charts indicated "comprehension gaps" (Peeck 1987, p. 141) in the learning process. It was not because they could not manage to work independently: they were used to such assignments, and had produced projects in written form. In searching for information, they had gone to the right database: relevant information organized in charts. However, it appears that they could neither extract information from a chart nor organize information in graphic form, nor use graphics to explain, represent, interpret or organize information. Nor did they attempt to integrate graphics with text. Most students did not seem to recognize the relationship between the two forms of communication: graphic and text. To most of them, graphics were a separate category irrelevant to text, neither something which facilitated the understanding of text nor another way of expressing information. In another project, when it was specified that they had to include graphics, many students produced essays on the topic, complete in themselves. Tagged on as an afterthought were a few pages of graphics which were not related 
or only remotely related to the essays. The graphics did not do justice to the rest of the project. They were not referred to in the text and they contributed nothing to the project. The students admitted that they had included them in the project to fulfil the requirement. Some even commented that including graphics in the project was a waste of time. It could probably be because they failed to see the representation, organization and interpretation functions of graphics. Their attitude towards graphics was negative.

In Division B, students had to interact with graphics in several assignments. However, they had more guidance from the teacher. With his own copy of the graphic on the overhead projector, the teacher showed the students step by step what to draw and how to draw and colour as well as how to look up and represent information in graphic form. It appears that having been shown "how to solve the task cognitively" (Pearson 1985, p. 730), students of Division B did not experience similar difficulties as students of Division A. Because they had been systematically shown how to represent information graphically, all students finished the assignments without difficulty.

Did Students Choose to Interact With Graphic Representation of Knowledge Structures When They Had a Choice?

When information was given in both text and graphic form, most students chose to look for information in text passages. To present a unit on whales, the teacher had distributed information sheets on the topic and made available to students a number of books on whales. The handouts consisted of seven pages, five of text passages and two of graphics. The assignment was to complete a classification table which included looking up the information sheets and reference books for the type, length, weight, colour, eating habits and home of various whales. All students with the exception of one Pakistani boy looked for information in the text passages, although the teacher had gone over the handouts with them. This indicated that the reason for not referring to the graphic was not that they did not understand it. It was probably because all the information was given in the text passages and the students found it simpler and more direct to copy the stated length of the whale from the text. Thus nobody took advantage of the graphic form.

In studying for tests, too, nearly all students depended on the printed word. Given a choice, not many of them chose to study the graphics or to answer the questions in graphic form. It appears that schools and teachers are biased towards verbal form of representation, and that students have been forced into the verbal format of 
learning by tradition (Winn 1987), and that "because teachers, parents and students tend to assign an inflated value to the printed word" (Fleming 1962, cited by Holliday 1975, p. 22) students are unwilling to invest their time and attention in graphics.

It is remarkable that after an experimental study administered on the same students (Tang 1989), the treatment of which was systematic teaching of one type of graphic representation of knowledge structures, a number of students actually used a graphic to answer two questions in a social studies assignment without any prompting from the teacher.

Did Graphic Representation of Knowledge Structures Facilitate Comprehension?

In Division $\mathrm{A}$, the follow-up activity of one of the projects was an oral presentation of their project followed by the answering of questions put to them by the teacher. Neither the oral presentation nor the question-answer session showed that graphics helped students to understand information. It could be either because students had not learned how to read and interpret information in charts; or because they could not write and organize information in graphic form; or because they did not quite know how to translate graphics into oral language; or because of all or some of these factors.

In the other Division where there was explicit teacher guidance on the use of graphics in certain assignments, examination of test papers showed that, although graphics might have facilitated understanding, only three or $10 \%$ of the students showed that they did. Not many students took advantage of graphics. One type merits special attention. The classification table seemed to have helped them understand and remember the information in the text passages. At least a number of students claimed that it did. Eight students maintained that organizing information in a classification table did help them to have a better understanding of the characteristics of whales.

Some of their responses were that the information in the table was simple, short, neatly arranged, organized, good for a quick review and good for comparing information. They seemed to recognize the role of the classification table as providing "an organizing scheme, which clarifies and represents spatial and structural relationships of elements of knowledge presented" (Peeck 1987, p. 128), thus facilitating learning. Those who were negative about the value of graphics explained that the chart was in note form, and they had to study sentences because in tests they had to write sentences. 
There are various reasons why graphics did not facilitate learning in a large percentage of students. Some of them did not recognize the function of the graphic, because teachers "spend little time training students to interpret pictures" (Holliday 1975, p. 22). Others felt that they had to learn in text form, probably because they had been taught to attach great importance to the printed word, and because of curricular demands such as tests and examinations. A few did not quite know how to translate graphics into text. Thus, most of them did not take full advantage of the graphics in instructional materials to facilitate learning.

\section{What are the Implications of These Findings for ESL and Content- area Teachers?}

Teachers can, perhaps, take full advantage of the graphics present in instructional materials, not only by drawing students' attention to them, but "by collecting and discussing examples from textbooks and from everyday reading" (Mohan 1986, p. 88), and by giving students systematic guidance on how to read, interpret, and use them. Teachers' guides accompanying recently published textbooks are an invaluable source to go to for methods of handling graphics.

Teachers can familiarize students with graphics by using tables and graphs "on the chalkboard or overhead projectors in explaining ideas" (Fry 1981, p. 388), or "as a way of previewing (or reviewing) content" (Mohan 1986, p. 89). They can help students develop the habit of always referring to illustrations in instructional materials; and enable them to use graphics "by making assignments just as they now do for writing" (Fry 1981, p. 388). "One standard task that students face is demonstrating their comprehension of a chapter or lecture by writing answers to questions. An alternative to such questions, and a convenient way to reach the same goal, is for students to fill out a table or line graph" (Mohan 1986, p. 88). Teachers can also encourage students to pay attention to graphics by requiring students to fill out tables or graphs as "an alternative to the various writing tasks" (Mohan 1986, p. 88) that face them. Perhaps, if test and examination questions were not set and answered exclusively in text form, students would be willing to learn to express knowledge in graphic form.

Unless teachers recognize the potential power of graphic representation of knowledge structures, and the role it plays in student learning, and take active steps to realize this potential, students will not benefit from graphics even if large quantities exist in the curriculum. 


\section{REFERENCES}

Ausubel, D. P. (1968). Educational psychology: A cognitive view. New York: Holt, Rinehart \& Winston.

Brody, P. J. (1984). The role of naturalistic inquiry on research in the instructional use of pictures. Paper presented at the American meeting of the Association for Educational Communication and Technology, Dallas. (ERIC Document Reproduction Service No. ED 243 411).

Burgess, R.C. (1984). In the field: An introduction to field research. London: George Allen \& Unwin.

Burnaby, B. (1987). Language for native, ethnic or recent immigrant groups: what's the difference. TESL Canada Journal, 4 (2), 9 - 27.

Duchastel, P. C. (1978). Illustrating instructional texts. Educational Technology, 18 (11), 36 - 39.

Duchastel, P. C. (1980). Research on illustrations in text: Issues and perspectives. Educational Communication and Technology, 23 (4), $283-287$.

Evans, M. A., Watson, C., \& Willows, D. M. (1987). A naturalistic inquiry into illustration in instructional textbooks. In D. M. Willows, \& H. A. Houghton (Eds.), The psychology of illustrations. Vol II. New York: Springer-Verlag, 86 - 115.

Fry, E. (1981). Graphical literacy. Journal of Reading, 25, 383 -390.

Fry, E. (1983). A theory of graphs for reading comprehension and writing communication. (ERIC Document Reproduction Service No. ED 240528 ).

Goldsmith, E. (1987). The analysis of illustration in theory and practice. In D.M. Willows, \& H.A. Houghton (Eds.), The psychology of illustration. Vol II. New York: Springer-Verlag, $53-85$. 
Herber, H.L. (1970). Teaching reading in content areas. Englewood Cliffs, New Jersey: Prentice-Hall.

Holliday, W.G. (1975). What's in a picture? The Science Teacher, $42,21-22$.

Holliday, W. G. (1976). Teaching verbal chains using flow diagrams and texts. A-V Communication Review, 24 (1), 63-78.

Hunter, B., Crismore, A., \& Pearson, P.D. (1987). Visual displays in Basal Readers and social studies textbooks. In D.M. Willows, \& H.A. Houghton (Eds.), The psychology of illustration, Vol II. New York: Springer-Verlag, 116 - 135.

Levie, W. H., \& Lentz, R. (1982). Effects of text illustrations: A review of research. Educational Communication and Technology, $30(4), 195-232$.

Levin, J. R., Anglin, G. J., \& Carney, R. N. (1987). On empirically validating functions of pictures in prose. In D. M. Willows, \& $\mathrm{H}$. A. Houghton (Eds.), The psychology of illustration. Vol I. New York: Springer-Verlag, 51 - 85.

Mohan, B.A. (1986). Language and content. Reading, Massachusetts: Addison-Wesley.

Mulcahy, P. \& Samuels, S. J. (1987). Three hundred years of illustrations in American textbooks. In D.M. Willows, \& H.A. Houghton (Eds.), The psychology of illustration, Vol II. New York: Springer-Verlag, 1 - 52.

Paivio, A. (1971). Imagery and verbal processes. New York: Holt, Rinchart, \& Winston.

Pearson, P. D. (1985). Changing the face of reading comprehension instruction. The Reading Teacher, 38 (8), 724 - 739.

Peeck, J. (1987). The role of illustrations in processing and remembering illustrated text. In D.M. Willows, \& H.A.Houghton (Eds.), The psychology of illustration, Vol I. New York: SpringerVerlag, 115 - 151. 
Schallert, D. L. (1980). The role of illustrations in reading comprehension. In R.J. Spiro, B.C. Bruce, \& W.F. Brewer (Eds.), Theoretical issues in reading comprehension: Perspectives from cognitive psychology, linguistics, artificial intelligence, and education. Hillsdale, New Jersey: Erlbaum, 503 - 524.

Spradley, J. P. (1980). Participant observation. New York: Holt, Rinehart, \& Winston.

Tang, G. M. (1989). Graphic representation of knowledge structures in ESL student learning. Unpublished doctoral dissertation. University of British Columbia.

Vacca, R. T. (1981). Content area reading. Boston: Little Brown \& Company.

Willows, D. M., \& Houghton, H. A. (1987). The psychology of illustration. New York: Springer-Verlag.

Winn, W. D. (1987). Charts, graphs and diagrams in educational materials. In D. M. Willows, \& H. A. Houghton (Eds.), The psychology of illustration, Vol I. New York: Springer-Verlag, 152 198.

Wolcott, H. F. (1987). Ethnographic research in education. In R.M. Jaeger (Ed.), Complementary methods for research in education. Washington, D.C.: American Educational Research Association, 187 - 211.

\section{THE AUTHOR}

Gloria M. Tang is Assistant Professor of ESL at the University of British Columbia, Vancouver, having previously been an ESL teacher/teacher-educator in Hong Kong for over twenty years. Her research interests include the development and use of teaching/ learning strategies (graphics) to enhance ESL student learning.

This article is based on her unpublished doctoral dissertation. 